\title{
Preparation of Aromatic Silanes as High Thermal Stability Coupling Agents
}

\author{
Youlin Pan ${ }^{1 \mathrm{a}}$, Barry Arkles ${ }^{1 \mathrm{~b}}$ and James Kendenburg ${ }^{1 \mathrm{c}}$ \\ ${ }^{1}$ Research and Development, Gelest Inc., 11 East Steel Rd, Morrisville, \\ PA 19067, USA \\ aypan@gelest.com; ${ }^{\mathrm{b}}$ executiveoffice@gelest.com; 'jkendenburg@gelest.com
}

Key words: Silylation, Grignard, Oganolithium, Hydrosilylation, Oganofunctional Silanes, Aromatic Silane, High Performance, High Thermal Stability.

\begin{abstract}
Four different synthetic methods for preparation of aromatic silanes have been developed and the hydrosilylation route has been proved to be one as the most commercially significant. A series of specialty aryl silanes have been synthesized for the potential applications of high performance and high temperature as silane coupling agents. The thermal stabilities of the bridged aromatic silanes have been examined using thermal gravimetric analysis(TGA) and compared against the gamma-substituted alkylsilanes and phenyltrimethoxysilane. These materials have greater thermal stability than the gamma-substituted, but marginally lower than phenyltrimethoxysilane.
\end{abstract}

\section{Introduction}

Organofunctional silanes are a class of fascinating compounds, they not only enable new and sophisticated materials to be developed, but also are served as the technologically advancingmaterials themselves. These include widely used coupling agent, adhesion promoter, surface modifier, crosslinker and moisture scavenger in many high technology industries such as automotive, aerospace, DNA microarray and microelectronics ${ }^{1,2,3,4}$.

Organofunctional silanes integrate the functionality of organic groups and the reactive inorganic silicates in the same molecule, act as molecular linkers between inorganic substrates and organic polymers, and bond those two dissimilar materials across boundaries.

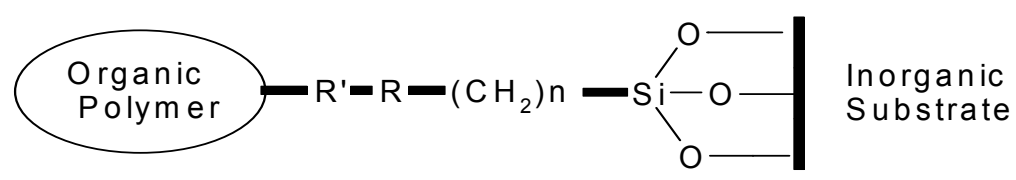

A general structure of the silane coupling agents is

\section{$(\mathrm{RO})_{3}-\mathrm{Si}-\left(\mathrm{CH}_{2}\right)_{\mathrm{n}}-\mathrm{X}$}

Where (RO) is a hydrolysable group such as methoxy, ethoxy or acetoxy, and $\mathrm{X}$ are the organofuncional groups of acetoxy, amino, mercapto, glycidoxy and methacryloxy etc. The commercial silane coupling agent has organic functionality separated from the silicon atom by three carbon atoms. Others common class of silanes separated by two or one carbon atom. They are commonly called as gamma-, beta- and alpha-substituted silane, while beta-substituted silane is generally not be used as coupling agent due to low thermal stability. The order of the thermal stability of those three kinds is depicted in the following chart: 


\section{Relative Thermal Stability of Silanes}

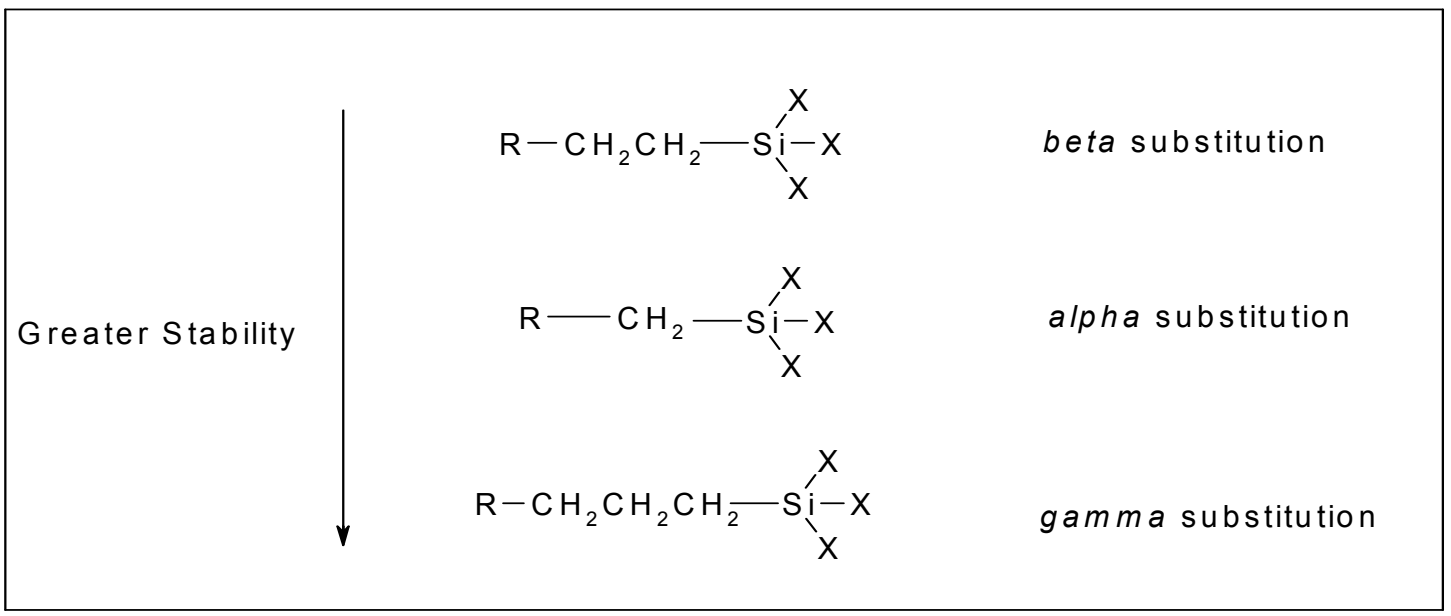

The gamma-substituted silanes have the highest thermal stability and can withstand short -term process condition of $350{ }^{\circ} \mathrm{C}$ and long-term continuous exposure of $160{ }^{\circ} \mathrm{C}^{5,6}$. However, this is not sufficient for some applications in the aerospace industry since they demand the composite materials to offer lightweight, high strength, extreme temperature and stiff weather resistant. Also because of their intractability and unreactivity, these types of materials often either cause poor bonding with the organic polymers or a loss of bond strength over times, strong adhesion of these two dissimilar materials in extreme high temperature environment are highly required $^{7,2}$.

\section{Experimental Section}

\section{Synthesis of Aromatic Silanes}

1. Ethyl-4-(triethoxysilyl)benzoate

A $500 \mathrm{~mL}$, 3-neck flask equipped with a magnetic stirrer, a pot thermometer and a water cooled condenser was charged with $1.1 \mathrm{~g}$ of $\mathrm{Rh}(\mathrm{acac})(\mathrm{cod})$ and $50 \mathrm{ml}$ of DMF. A mixture of $55.2 \mathrm{~g}(0.2$ $\mathrm{mol})$ of 4-Iodoacetophenone, $50.0 \mathrm{~g}(0.3 \mathrm{~mol})$ of $(\mathrm{EtO})_{3} \mathrm{SiH}, 50.6 \mathrm{~g}(0.5 \mathrm{~mol})$ of $^{\mathrm{Et}}{ }_{3} \mathrm{~N}$ and $150 \mathrm{ml}$ of DMF was added at a pot temperature of $80{ }^{\circ} \mathrm{C}$ over $1 \mathrm{~h}$. After heating at $80{ }^{\circ} \mathrm{C}$, the pot mixture was cooled to room temperature, $200 \mathrm{ml}$ of dry ether was then added. The mixture was filtered and the salts were washed with $750 \mathrm{ml}$ of heptanes two times. The filtrates was combined and subjected to high vacuum distillation:43.7 g(yield:69.9\%) of pale yellow liquid were obtained; bp: 119-121 ${ }^{\circ} \mathrm{C} / 0.3 \mathrm{mmHg}$; IR and NMR are consistent with the target structure. Density of the product at $20{ }^{\circ} \mathrm{C}$ : 1.029 .

2. 4-(Triethoxysilyl)acetophenone

This compound can prepared in the same manner by using 4-Iodoacetophenone yield $56.1 \%$ as pale yellow liquid; bp: $119-121^{\circ} \mathrm{C} / 0.3 \mathrm{mmHg}$; IR and NMR are consistent with the target structure. Density of the product at $20{ }^{\circ} \mathrm{C}: 1.017$.

3. 4-Aminophenyltrimethoxysilane

A 12L, 4-neck flask equipped with a mechanical stirrer, a pot thermometer, and additional

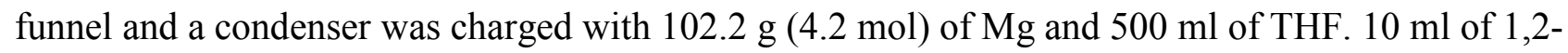
dibomoethane was dropped into the pot to initiate the reaction, $1265.0 \mathrm{~g}(4.0 \mathrm{~mol})$ of bis(trimethylsilylamino)phenyl bromide in $4 \mathrm{~L}$ of THF was then slowly added at a pot temperature 
of 40 to $60{ }^{\circ} \mathrm{C}$ over $5 \mathrm{~h}$. After heated at $60{ }^{\circ} \mathrm{C}$ for another $5 \mathrm{~h}$, the Grignard solution was cooled to room temperature and pushed out into a $2 \mathrm{X} 4 \mathrm{~L}$ bottle under the protection of $\mathrm{N}_{2}$. $1826.6 \mathrm{~g}$ (12.0 mol) of $\mathrm{Si}\left(\mathrm{OCH}_{3}\right)_{4}$ were charged into above reactor, followed by addition of the fresh made Grignard solution through additional funnel at a pot temperature of 30 to $40{ }^{\circ} \mathrm{C}$. After heated at 40 ${ }^{\circ} \mathrm{C}$ for $2 \mathrm{~h}, 5$ fold excess of $\mathrm{MeOH}$ was added into the pot. The mixture was heated at $40{ }^{\circ} \mathrm{C}$ for another $6 \mathrm{~h}$, cooled to room temperature, filtered to give a clean solution. The filtrates was then subjected to high vacuum distillation: $373.4 \mathrm{~g}$ (yield: $46.6 \%$ ) of pale yellow liquid were obtained; bp: $114-6{ }^{\circ} \mathrm{C} / 0.5 \mathrm{mmHg}$; IR and NMR are consistent with the target structure. It becomes solids when cooled to room temperature; $\mathrm{mp}: 60-2{ }^{\circ} \mathrm{C}$.

4. Tolyltrimethoxysilane

A 12L, 4-neck flask equipped with a mechanical stirrer, a pot thermometer, an additional funnel and a condenser was charged with $97.2 \mathrm{~g}(4.0 \mathrm{~mol})$ of $\mathrm{Mg}$ and $500 \mathrm{ml}$ of THF. $10 \mathrm{ml}$ of 1,2dibomoethane was dropped into the pot to initiate the reaction, $684.1 \mathrm{~g}(4.0 \mathrm{~mol})$ of 4-bromotoluene in $4 \mathrm{~L}$ of THF was then slowly added at a pot temperature of 30 to $40{ }^{\circ} \mathrm{C}$ over $6 \mathrm{~h}$. After heated at 40 ${ }^{\circ} \mathrm{C}$ for another $3 \mathrm{~h}$, the Grignard solution was cooled to room temperature and pushed out into another flask under the protection of $\mathrm{N}_{2}$. $1826.6 \mathrm{~g}(12.0 \mathrm{~mol})$ of $\mathrm{Si}(\mathrm{OCH} 3)_{4}$ were charged into above reactor, followed by addition of the fresh made Grignard solution through additional funnel at a pot temperature of 30 to $40{ }^{\circ} \mathrm{C}$. The mixture was heated at $80{ }^{\circ} \mathrm{C}$ for 6 h to remove ca $3.0 \mathrm{~L}$ of THF and addition of $3.0 \mathrm{~L}$ of heptanes. The mixture was then cooled to room temperature, filtered to give a clean solution. The filtrates was then subjected to high vacuum distillation: $540.4 \mathrm{~g}$ (yield: $67.0 \%$ ) of pale yellow liquid were obtained, bp: $75-8{ }^{\circ} \mathrm{C} / 8 \mathrm{mmHg}$; IR and NMR are consistent with the target structure. Density of the product at $20^{\circ} \mathrm{C}: 1.033$.

\section{Biphenyltrimethoxysilane}

A 5L, 4-neck flask equipped with a mechanical stirrer, a pot thermometer, an additional funnel and a condenser was charged with $466.2 \mathrm{~g}(2.0 \mathrm{~mol})$ of biphenyl bromide in $2 \mathrm{~L}$ of THF. After cooled to $-78{ }^{\circ} \mathrm{C}, 1200 \mathrm{~mL}$ of $\mathrm{n}$-BuLi $(1.7 \mathrm{M}$ in hexane, $2.0 \mathrm{~mol})$ was added slowly while vigorously stirring. After stirring for $30 \mathrm{~min}$. at $-78^{\circ} \mathrm{C}$, the mixture was slowly warmed up to room temperature and continued to stir for 4 hours at room temperature. $913.3(6.0 \mathrm{~mol})$ of $\mathrm{Si}\left(\mathrm{OCH}_{3}\right)_{4}$ were charged into another reactor, followed by addition of the fresh made Lithium reagent through additional funnel at a pot temperature of 10 to $20{ }^{\circ} \mathrm{C}$. The mixture was stirred at $80{ }^{\circ} \mathrm{C}$ for $6 \mathrm{~h}$ to remove ca $1.5 \mathrm{~L}$ of THF and addition of $1.5 \mathrm{~L}$ of heptanes. The mixture was filtered and the salt was washed with $500 \mathrm{ml}$ of dry heptanes two times. The filtrates was combined and subjected to high vacuum distillation: $312.9 \mathrm{~g}$ (yield: $57.0 \%$ ) of pale yellow liquid were obtained, bp: $133-5{ }^{\circ} \mathrm{C} / 0.3$ $\mathrm{mmHg}$; IR and NMR are consistent with the target structure. Density of the product at $20{ }^{\circ} \mathrm{C}: 1.026$.

6. 1-Napthyltrimethoxysilane

This compound can prepared in the same manner as Biphenyltrimethoxysilane by using biphenyl bromide: yield $49.3 \%$ as pale yellow liquid; bp: $152{ }^{\circ} \mathrm{C} / 2 \mathrm{mmHg}$; IR and NMR are consistent with the target structure. It becomes solids when cooled to room temperature; mp: $33-5$ ${ }^{\circ} \mathrm{C}$.

7. Styrylethyltrimethoxysilane

A 12L, 4-neck flask equipped with a mechanical stirrer, a pot thermometer, dual additional funnels and a condenser was charged with $4 \mathrm{~g}$ of phenothiazine and $500 \mathrm{~g}$ (ca 0.6 liters) of Heptane. After heat to $90{ }^{\circ} \mathrm{C}, 4 \mathrm{~g}$ of $10 \mathrm{wt} \% \mathrm{CPA} / \mathrm{THF}$ catalyst solution was added into the pot, 2055.2 $\mathrm{g}(12 \mathrm{~mol})$ of DVB and $1918.3 \mathrm{~g}(14 \mathrm{~mol})$ of TCS were added through the separated funnels at 
a rate to maintain reaction temperature between $70-80{ }^{\circ} \mathrm{C}$, do not let either the DVB or TCS addition get ahead of the other. The pot mixture was heated at $80{ }^{\circ} \mathrm{C}$ for $2 \mathrm{~h}$ after addition was completed. The volatiles was removed till pot temperature of $80{ }^{\circ} \mathrm{C}$ with $1 \mathrm{mmHg}$, the pot remain was esterified at 80 to $120{ }^{\circ} \mathrm{C}$ to convert chlorosilane to alkoxysialne, then subjected to WIFE distillation to give $100.3 \mathrm{~g}$ (yield: $27.7 \%$ ) of pale yellow liquid, bp: $98{ }^{\circ} \mathrm{C} / 0.1 \mathrm{mmHg}$; IR and NMR are consistent with the target structure. Density of the product at $20{ }^{\circ} \mathrm{C}: 1.023$.

\section{Chloromethylphenylethyltrimethoxysilane}

A 12L, 4-neck flask equipped with a mechanical stirrer, a pot thermometer, dual additional funnels and a condenser was charged with $2 \mathrm{~g}$ of BHT and $500 \mathrm{~g}$ (ca 0.65 liters) of Heptane. After heat to $90{ }^{\circ} \mathrm{C}, 4 \mathrm{~g}$ of $10 \mathrm{wt} \% \mathrm{CPA} / \mathrm{THF}$ catalyst solution was added into the pot, $3804 \mathrm{~g}(25 \mathrm{~mol})$ of VBC and $3702 \mathrm{~g}(27.5 \mathrm{~mol})$ of TCS were added at a volume ratio of $\sim 1.1: 1$ through the separated funnels at a rate to maintain reaction temperature between $95-100{ }^{\circ} \mathrm{C}$, do not let either the VBC or TCS addition get ahead of the other. The pot mixture was heated at $100{ }^{\circ} \mathrm{C}$ for 4 to $6 \mathrm{~h}$ after addition was completed. The volatiles was removed till pot temperature of $80 \mathrm{oC}$ with $1 \mathrm{mmHg}$, the pot remain was treated with esterified at 80 to $120{ }^{\circ} \mathrm{C}$ to convert chlorosilane to alkoxysialne, then subjected to high vacuum distillation to give $5041 \mathrm{~g}$ (yield: $73.2 \%$ ) of pale yellow liquid, bp: 115 ${ }^{\circ} \mathrm{C} / 1.5 \mathrm{mmHg}$; IR and NMR are consistent with the target structure. Density of the product at $20{ }^{\circ} \mathrm{C}$ : 1.092 .

\section{Results and Discussion}

It has been showed that extremely high thermal stability can obtained through aromatic silane coupling agents. The specific substitution on benzene ring also plays a significant role in their thermal stability, while electron withdrawing substitution reduces thermal stability, electropositive groups enhance thermal stability ${ }^{6}$.

Continue our systematically studies on the organofunctional silanes $8,9,10,11$,

we have developed four different approaches for preparation of aromatic silanes and synthesized a series of specialty aryl silanes:

\section{Route One: Silylation of Functional Halogenated Aromatics ${ }^{12}$}

Silylation of aryl iodides by triethoxysilane in the presence of ruthenium catalyst affords compound 1 and 2.<smiles>CCOCCCCCOCc1ccc(I)cc1</smiles>

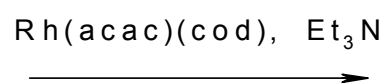

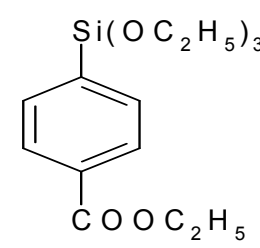

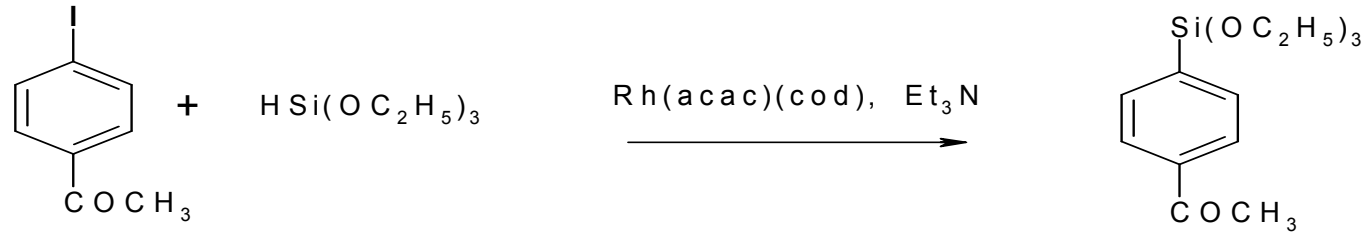




\section{Route Two: Grignard Intermediates ${ }^{13}$}

Compound $\mathbf{3}$ is obtained by preparation of a Grignard regent from N,N-bis(trimethylsily)-pbomomaniline and $\mathrm{Mg}$ in THF, reacting with tetramethoxysilane and deprotecting with methanol.

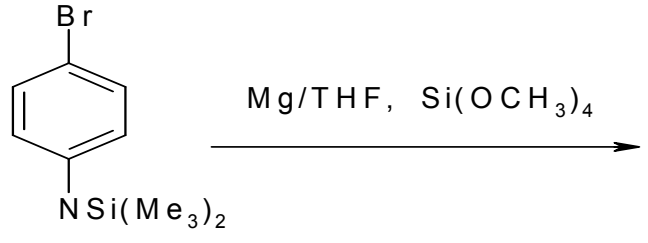<smiles>CO[Si]c1ccc(N(C)C)cc1</smiles>

Compound $\mathbf{4}$ are conviencely synthesized through Grignard route from the correspond aryl bromides, Mg turnings, tetramethoxysilane in THF.<smiles>Cc1ccc(Br)cc1</smiles><smiles>Cc1ccc(Br)cc1</smiles>

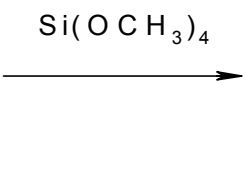<smiles>COc1ccc(C)cc1</smiles>

\section{Route Three: Lithium Reagents ${ }^{14}$}

Although compounds $\mathbf{5}$ and $\mathbf{6}$ can also be prepared from the correspond aryl bromides, $\mathrm{Mg}$ turnings, tetramethoxysilane in THF, organolithium reagents offers the advantages of shorter reaction times and higher yield.

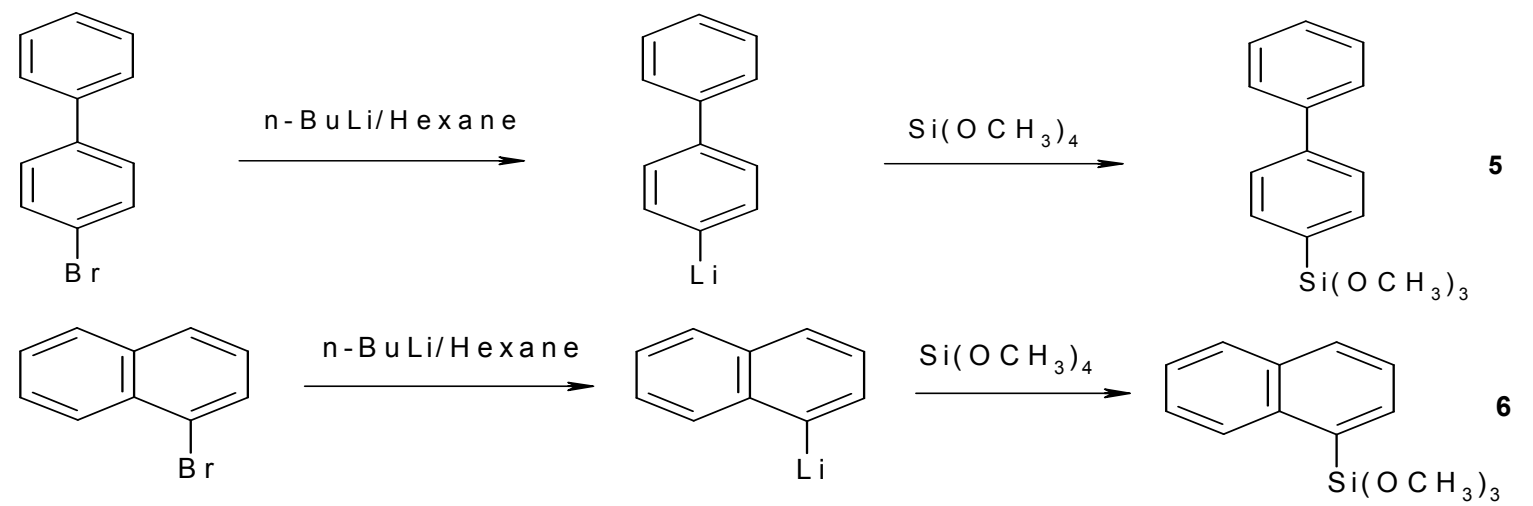

\section{Route Four: Hydrosilylation ${ }^{15,16,17,18}$}

Hydrosilylation of the corresponding vinyl monomers with CPA as catalyst yields the precursors of compound $\mathbf{7}$ and $\mathbf{8}$. The precursors are then converted into the compound $\mathbf{7}$ and $\mathbf{8}$ by alkoxylation.<smiles>C=Cc1ccc(C=C)cc1</smiles>

\section{$\mathrm{HSiCl}_{3} / \mathrm{CPA}$}

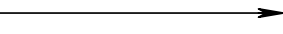

$\mathrm{HSiCl}_{3} / \mathrm{CPA}$
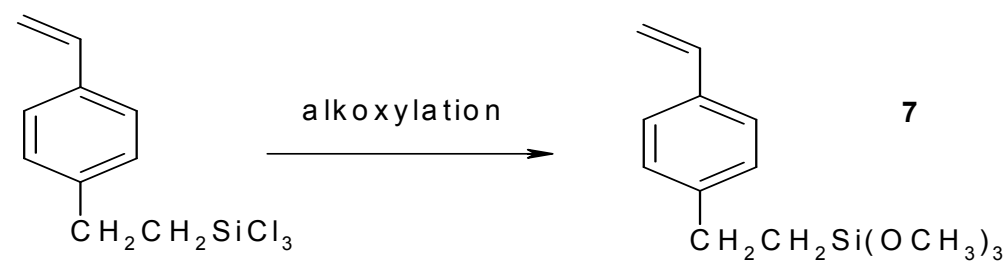<smiles>C=Cc1ccc(CCl)cc1</smiles>

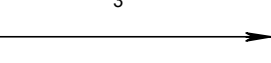

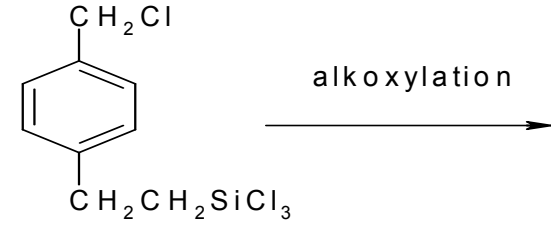


Out of above four routes, the hydrosilylation route has been proved to be one as the most commercially significant. It not only just produced the desired product in high yield and most economic, but also compound $\mathbf{8}$ can also be serviced as starting materials for other functional aromatic silanes.
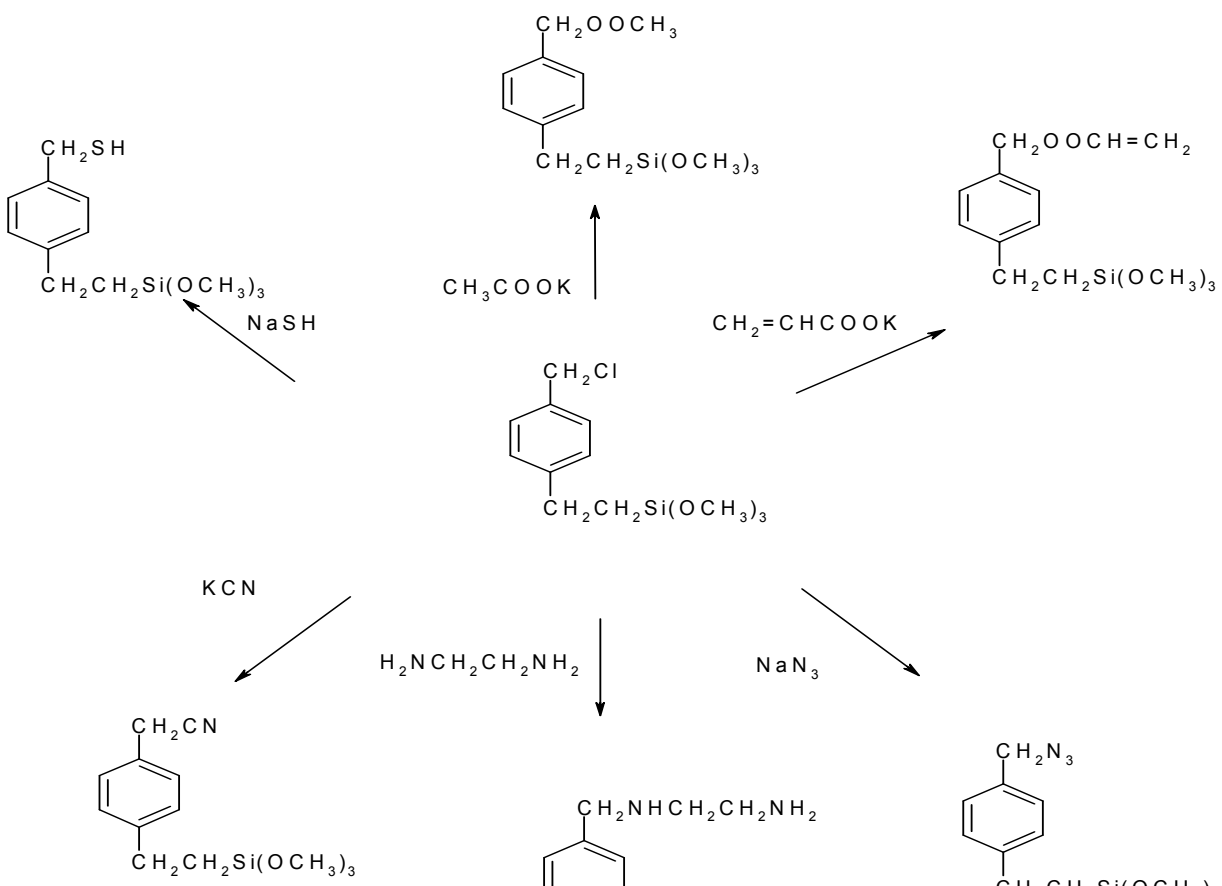

$\mathrm{H}_{2} \mathrm{NCH}_{2} \mathrm{CH}_{2} \mathrm{NH}_{2}$
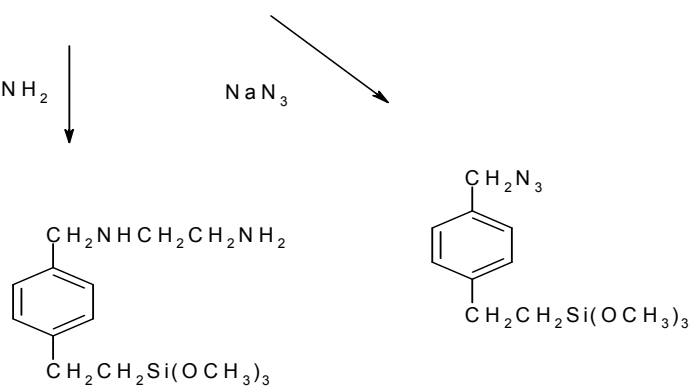

The thermal stabilities of some aromatic silanes have been examined using thermal gravimetric analysis(TGA) ${ }^{19}$ and compared against the gamma-substituted functional alkylsilanes and phenyltrimethoxysilane. Their thermal stability data can be summered in the following table:

\section{Thermal Stability of Silanes}

\begin{tabular}{|c|c|}
\hline $\mathrm{ClCH}_{2} \mathrm{CH}_{2} \mathrm{CH}_{2} \mathrm{Si}\left(\mathrm{OCH}_{3}\right)_{3}$ & $360^{\circ} \mathrm{C}$ \\
\hline $\mathrm{H}_{2} \mathrm{NCH}_{2} \mathrm{CH}_{2} \mathrm{NHCH}_{2} \mathrm{CH}_{2} \mathrm{CH}_{2} \mathrm{Si}\left(\mathrm{OCH}_{3}\right)_{3}$ & $390 \circ \mathrm{C}$ \\
\hline $\mathrm{CH}_{2} \mathrm{CH}_{2} \mathrm{CH}_{2} \mathrm{Si}\left(\mathrm{OCH}_{3}\right)_{3}$ & $395{ }^{\circ} \mathrm{C}$ \\
\hline$\left(\mathrm{OCH}_{3}\right)_{3}$ & $530^{\circ} \mathrm{C}$ \\
\hline $\left.\mathrm{OCH}_{3}\right)_{3}$ & $485^{\circ} \mathrm{C}$ \\
\hline$\left(\mathrm{OCH}_{3}\right)_{3}$ & $510 \circ \mathrm{C}$ \\
\hline${ }_{2} \mathrm{CH}_{2} \mathrm{Si}\left(\mathrm{OCH}_{3}\right)_{3}$ & $495^{\circ} \mathrm{C}$ \\
\hline$\searrow-\mathrm{CH}_{2} \mathrm{CH}_{2} \mathrm{Si}\left(\mathrm{OCH}_{3}\right)_{3}$ & $435^{\circ} \mathrm{C}$ \\
\hline$-\mathrm{CH}_{2} \mathrm{CH}_{2} \mathrm{Si}\left(\mathrm{OCH}_{3}\right)_{3}$ & $460^{\circ} \mathrm{C}$ \\
\hline
\end{tabular}


From this study ${ }^{20}$ we learnt that the bridged aromatic silanes have greater thermal stability than the gamma-substituted functional alkylsilanes, but marginally lower than phenyltrimethoxysilane.

\section{Summary}

1. Four different synthetic methods for aromatic silanes have been developed and the hydrosilylation route has been proved to be one as the most commercially significant.

2. A series of specialty aryl silanes have been synthesized for the potential applications of high performance and high temperature as silane coupling agents. The thermal stabilities of the aromatic silanes have been examined using thermal gravimetric analysis(TGA) and compared against the gamma-substituted alkylsilanes and phenyltrimethoxysilane.

3. These materials have greater thermal stability than the gamma-substituted, but marginally lower than phenyltrimethoxysilane.

\section{References}

[1] E. Plueddemann, "Silane Coupling Agents" Plenum, 1982

[2] P. Pape et al, "Silanes and Other Coupling Agents" VSP, 1992

[3] B. Arkles, Tailoring Surfaces with Silanes, CHEMTECH, 7, 1977, 766-778

[4] J. Blitz and C. Little, "Fundamental \& Applied Aspects of Chemically Modified Surfaces"

[5] Royal Society of Chemistry, 1999

[6] W. Noll “CHEMISTRY AND TECHNOLOGY OF SILICONES” Academic Press, 1968

[7] B. Arkles. "Silane Coupling Agents: Connecting Across Boundaries" Gelest Inc. 2006

[8] W. Hill et al, Poly. Mat. Sci. Eng., 62, 1990, 668

[9] B. Arkles, Y. Pan, G. L. Larson, D. Berry, "Silanes and Coupling Agents", Vol. 3, 2004, 179

[10]B. Arkles, Y. Pan, Y.K. Kim, "Silanes and Coupling Agents", Vol. 5, 2009, 51

[11]B. Arkles, Y. Pan, Y.K. Kim, E. Eisenbraun, C. Miller, A. E. Kaloyeros, J. Adhesion Science and Technology, Vol. 25, 2011,12

[12] Y. Pan, B. Arkles, E. Eisenbraun, A. E. Kaloyeros, Advanced Materials Research ,Vols. $415-$ 417, 2012, 1829-1836

[13] M. Murata et al. Tetrahedron ,63, 2007, 4087

[14] A. Manoso et al. J. Org. Chem. 69, 2004, 8305

[15]K. Shea, L. Douglas and O. Webster, Chemistry of Materials, 1, 1989, 574

[16]J. Speier, J. Webster and G. Barnes J. Am. Chem. Soc., 79,1957, 974-979

[17]H. Renner et al "Platinum group metals and compounds". Ullmann's Encyclopedia of Industrial Chemistry. Wiley, 2002

[18]C. Elschenbroich," Organometallics”, Wiley and Sons-VCH: Weinheim, 2006

[19]B. Karstedt US Patent, 3,775,452, 1973

[20]E. P. Plueddeman Modern Plastics 43, 1966, 131

[21]B. Arkles and W. Peterson "Modern Plastics", 67, 1980, 64 